\title{
Reviewing Emotional Intelligence Levels and Time Management Skills among Students of School of Physical Education and Sports
}

\author{
Ziya Bahadir $^{1}$ \\ ${ }^{1}$ School of Physical Education and Sports, Erciyes University, Kayseri, Turkey \\ Correspondence: Ziya Bahadir, School of Physical Education and Sports, Erciyes University, Kayseri, Turkey.
}

Received: March 21, 2018

Accepted: April 5, $2018 \quad$ Online Published: May 15, 2018

doi:10.5539/jel.v7n4p114

URL: https://doi.org/10.5539/jel.v7n4p114

\begin{abstract}
This study aimed at exploring emotional intelligence levels and time management skills of students of school of physical education and sports (SPES) and assessing their emotional intelligence levels and time management skills in terms of some variables. 309 students who studied at SPES of Erciyes University during the 2017-2018 academic year participated in the study that was designed in screening model. In order to determine participant students' emotional intelligence levels and time management skills; "Schutte Emotional Intelligence Scale"-Turkish adaptation of which was performed by Tatar, Tok, \& Saltukoğlu (2011) and Time Management Inventory - Turkish adaptation of which was performed by Alay \& Koçak (2002) were used as data collection tools. In the study; Mann-Whitney U Test and Independent-Samples $\mathrm{T}$ Test were employed for paired comparisons while One Way Anova and Kruskal Wallis Test were used for multiple comparisons. For measurement of correlations, Pearson Correlation Analysis technique was used. According to study results, emotional intelligence levels and time management skills of students of school of physical education and sports were at "moderate level". Students' emotional intelligence levels differed significantly in terms of sex, academic grades and academic departments but not in terms of type of high school, sportive branch and age. Students' time management skills did not change considerably in terms of age, sex, sportive branch, type of high school, academic grades and academic departments. Moreover, a positive and significant correlation existed between students' emotional intelligence levels and time management skills.
\end{abstract}

Keywords: emotional intelligence, time management, students of school of physical education and sports

\section{Introduction}

Over the past years there has been an increasing interest in and awareness towards emotional intelligence, which is regarded as one of intelligence types. Under this increasing interest in and awareness towards emotional intelligence, there are difficulties caused by excessive conflicts experienced in both professional life and private life, loss of energy and inability to manage performance, dissatisfaction with life and difficulties to manage the emerging negative emotions (Erdoğdu, 2008).

Individuals of the modern era, shaped by intense and fast changes, have started to live with bigger number of and different people in diversified environments as compared to the past; which makes them take up numerous roles in different situations and scenarios. Individuals' realizing these roles in a successful manner affects each aspect of their lives. It is a fact that classical intelligence approaches fail to realize these roles in a successful manner and therefore it has been an accepted reality that it is individuals' emotional intelligence that optimizes these roles (Dökmen, 2004).

With the simplest meaning; emotional intelligence is reasonable use of feelings (Weissinger, 1998). Emotional intelligence is a mental ability that helps individuals understand their own emotions and others' feelings. Emotional intelligence is not only having emotions but also understanding what they mean. This is bilateral; on the one hand there is mind that tries to understand emotions; on the other hand, there are feelings and emotions that take individuals to mental processes and produce creative thoughts (Epstein, 1999). Erik Erikson defines emotional intelligence as a skill to integrate one's various dimensions in successful way -in other words, as the integrity of self-identity (James, 1997; Ural, 2001).

Emotional intelligence includes all the skills that are necessary for people to command emotions in a controlled manner, to develop healthy and compatible relations and to lead a happy life. Besides; emotional intelligence is 
making individuals know their own values and strength so that they can live a more productive and effective life. Emotional intelligence can be characterized as a composition of emotional qualities such as tranquility, effort, perseverance and emotions so that people can motivate themselves and others (Konrad \& Hendl, 2003, p. 13).

Salovey \& Mayer (1990) explain emotional intelligence as the subset of social intelligences that cover the ability to monitor one's own feelings and emotions, to distinguish among them, and to employ this information to direct one's thinking. According to this theoretical approach, emotional intelligence emphasizes integration of feelings and intelligence (Mayer \& Salovey, 1997).

Time management is showing an effort to use time -a precious resource- in reaching goals and objectives productively. Today; using time or time management is very important for people. Importance of time management does not solely mean controlling time but controlling time is one of the most crucial elements that enhance peoples' lives (Alay, 2000).

As in management of other resources, time management requires analysis, planning and programming. Time management is realized through correct planning, determining priorities and organizing objectives and goals completely (Haynes, 1999).

Generally, most people do not know how to manage time effectively. Those who are individually unable to use time are professionally unable to use work-lives and private lives, too. The best way to use time correctly requires individuals to manage and to plan their lives most effectively (Keenan, 1996).

Human beings are incapable of managing time. Although they have biological clock like other organisms, as proved by psychological experiments; they do not have a reliable sense of time (Güçlü, 2001). Managing time needs personal skills and persistence. It is necessary to use time economically under a plan in order to achieve productivity. Any moment spent is a treasure (Karaoğlan, 2006).

Managing time is -in a sense- to participate in life in satisfactorily as time passes constantly. Time management is -in fact- the course of knowing the value of life. If we are unable to control time, it means that we are unable to control ourselves. We need to have more appropriate, healthier and more useful habits to control ourselves (Gün, 2006). It is essential that individuals themselves plan their time in time management and in the meantime, individuals need to be willing to manage their own time (Karaköse, 2009).

As one of the sportive organizations, schools of physical education and sports educate future physical education teachers, trainers/coaches, sports-managers and recreationists. Considering their future positions, emotional intelligence levels and time management skills matter for these students and therefore it is thought that it is worth investigating these characteristics of these students. Besides, when the literature was examined, it was seen that there were not any comprehensive studies that investigated emotional intelligence levels and time management skills of the students of school of physical education and sports. This study was important for these reasons, too.

Basic objective of this study was to exploring emotional intelligence levels and time management skills of students of school of physical education and sports (SPES). Besides, the study also aimed at assessing their emotional intelligence levels and time management skills in terms of such variables as age, sex, academic grades, academic departments, sportive branches and type of high school.

\section{Methodology of Research}

\subsection{Study Model}

This was a study that was designed in general screening model and investigated emotional intelligence levels and time management skills of students who studied at school of physical education and sports. Screening Model is a research approach that aims to describe a situation either as it was before or as it is now (Karasar, 2008).

\subsection{Study Group}

The study group was consisted of 309 students who studied at SPES of Erciyes University during the 2017-2018 academic year and were randomly sampled. 154 of the participant students were female $(49.8 \%)$ whereas 155 of them were male (50.2\%). 84 of these students attended 1st grade, 58 students 2 nd grade, 104 students 3 rd grade and 63 students 4 th grade. Average age of the students was 21.20 years.

\subsection{Data Collection Tools}

In order to obtain students' demographic characteristics, a Personal Information Form that was developed by the researchers was used. In order to explore students' emotional intelligence levels, Schutte Emotional Intelligence 
Scale was used and in order to measure students' time management skills, Time Management Inventory were used.

Schutte Emotional Intelligence Scale was developed by Schutte, Malouff, Hall, Haggerty, Cooper, Golden, \& Dornheim (1998) but revised by Austin, Saklofske, Huang, \& McKenney (2004) under 41 items. Its Turkish adaptation was performed by Tatar, Tok, \& Saltukoğlu (2011) and has a three factor structure (Optimism, Awareness-of-Emotions and Use-of-Emotions). The scale is designed in five point Likert format and each item is rated as "strongly disagree", "disagree", "neutral", "agree", "strongly agree" in order to explore emotional intelligence levels. Reliability and validity analyses of the scale were done and split half reality coefficients were .69 for the first split and .71 for the second split. Guttman Split-Half and Spearman-Brown coefficient for non equal splits was .78 and correlation coefficient between two splits was found to be .64. One week correlation coefficient of test-retest reliability for the whole scale was $\mathrm{r}=0.49$ while two week correlation coefficient was $\mathrm{r}=0.56$. Internal consistency coefficient of the Turkish version of the scale was .82 . Cronbach-Alpha internal consistency coefficients of the factors were .75 for Optimism, .39 for Use-of-Emotions and .76 for Awareness-of-Emotions (retrieved by Ünlü et al., 2016). Higher scores obtained from the scale indicate higher level of emotional intelligence.

Time Management Inventory was designed by Britton \& Tesser (1991) and its Turkish adaptation was performed by Alay \& Koçak (2002). There are a total of 27 items in the inventory. The inventory was developed in three factors "Long-range planning", "Time attitudes" and "Short-range planning". The inventory is designed in five point Likert format and each item is rated as "always", "frequently", "sometimes", "infrequently", "never". In the study of reliability and validity tests done by Alay \& Koçak (2002), Cronbach Alpha coefficients of the inventory were .88 for Long-range planning, .66 for Time attitudes and .47 for Short-range planning and .87 for the whole inventory. Higher scores obtained from the scale mean that individuals are good at time management.

\subsection{Statistical Analyses}

Statistical analyses were done using SPSS package program. In order to examine emotional intelligence levels and time management skills of the students of school of physical education and sports; such descriptive statistics as arithmetic averages $(\bar{X})$ and standard deviation (Sd) were used.

In the analyses, whether or not data followed a normal distribution was investigated through Kolmogorov-Smirnov Test. As a result, it was found that emotional intelligence scores did not follow normal distribution $(\mathrm{p}=.000)$ whereas time management scores followed a normal distribution $(\mathrm{p}=.200)$.

Due to emotional intelligence scores not following a normal distribution, Mann-Whitney U Test was employed for paired comparisons and Kruskal Wallis Test for multiple comparisons. The accepted level of significance for all analyses was $\mathrm{p}<0.05$.

Because time management scores followed a normal distribution, Independent-Samples $\mathrm{T}$ Test was used for paired comparisons and One Way Anova for multiple comparisons. The accepted level of significance for all analyses was $\mathrm{p}<0.05$.

Besides, Pearson Correlation Analysis technique was used in order to understand whether or not a correlation between emotional intelligence level and time management skills existed.

\section{Results of Research}

Table 1. Distribution of participant SPES students in terms of their demographic characteristics

\begin{tabular}{|c|c|c|c|c|c|}
\hline Sex & $\mathrm{n}$ & $\%$ & Academic department & $\mathrm{n}$ & $\%$ \\
\hline Male & 155 & 50.2 & Teaching & 103 & 33.3 \\
\hline \multirow[t]{2}{*}{ Female } & 154 & 49.8 & Training & 33 & 10.7 \\
\hline & & & Management & 79 & 25.6 \\
\hline Age & $\mathrm{n}$ & $\%$ & Recreation & 94 & 30.4 \\
\hline $18-20$ years & 122 & 39.5 & & & \\
\hline 21-23 years & 148 & 47.9 & Academic grade & $\mathrm{n}$ & $\%$ \\
\hline \multirow[t]{2}{*}{$24-26$ years } & $\begin{array}{l}140 \\
39\end{array}$ & 12.6 & $1^{\text {st }}$ grade & 84 & 27.2 \\
\hline & & & $2^{\text {nd }}$ grade & 58 & 18.8 \\
\hline Type of high school & $\mathrm{n}$ & $\%$ & $3^{\text {rd }}$ grade & 104 & 33.7 \\
\hline General high school & 205 & 66.3 & $4^{\text {th }}$ grade & 63 & 20.4 \\
\hline Vocational high school & 104 & 33.7 & & & \\
\hline Sportive branch & $\mathrm{n}$ & $\%$ & Total n: 309 & & \\
\hline Team sports & 182 & 58.9 & & & \\
\hline Individual sports & 127 & 41.1 & & & \\
\hline
\end{tabular}


154 students were female (49.8\%) while 155 students were male $(50.2 \%)$; 122 students $(39.5 \%)$ belonged to 18-20 age group, 148 students (47.9) to 21-23 age group and 39 students (12.6\%) to 24-26 age group. In terms of distributions according to academic departments; 103 students (33.3\%) attended teaching department of physical education and sports, 33 students (10.7\%) department of training, 79 students $(25.6 \%)$ department of sports management and 94 students (30.4\%) department of recreation. 84 of the students $(27.2 \%)$ studied in 1st grade, 58 students $(18.8 \%)$ in the 2 nd grade, 104 students $(33.7 \%)$ in the $3^{\text {rd }}$ grade and 63 student $(20.4 \%)$ in the 4 th grade. 205 of the students $(66.3 \%)$ graduated from general high schools and 104 students $(33.7 \%)$ from vocational high schools. As for sportive branches; 182 students (58.9\%) were engaged in team sports whereas 127 students $(41.1 \%)$ were engaged in individual sports.

Table 2. Average scores of SPES students from total emotional intelligence scale and its subdimensions

\begin{tabular}{llll}
\hline Emotional Intelligence Scale & $\mathrm{n}$ & $\overline{\mathrm{X}}$ & $\mathrm{SD}$ \\
\hline Optimism & 309 & 3.66 & .710 \\
Awareness-of-Emotions & 309 & 3.19 & .779 \\
Use-of-Emotions & 309 & 2.99 & .722 \\
General Average Scores & 309 & 3.40 & .468 \\
\hline
\end{tabular}

Table 2 presented the participant SPES students' average scores obtained from total Emotional Intelligence Scale and its subdimensions. Accordingly; it was found that students' total average score from the Emotional Intelligence Scale was $\bar{X}=3.40$. Besides, students' average score was $\bar{X}=3.66$ from Optimism subdimension, $\overline{\mathrm{X}}=3.19$ from Awareness-of-Emotions subdimension and $\overline{\mathrm{X}}=2.99$ from Use-of-Emotions subdimension.

Table 3. Comparison of SPES students' emotional intelligence levels in terms of age, academic grades and academic department variables

\begin{tabular}{lllllllll}
\hline & & $\mathrm{n}$ & $\overline{\mathrm{X}}$ & $\mathrm{Sd}$ & $\mathrm{SD}$ & $\chi^{2}$ & $\mathrm{p}$ & Difference \\
\hline \multirow{4}{*}{ Age } & $18-20$ & 122 & 3.42 & .465 & & & & \\
& $21-23$ & 148 & 3.37 & .465 & 2 & 0.910 & 0.634 & No \\
& $24-26$ & 39 & 3.41 & .492 & & & & \\
& & & & & & & & \\
Academic & $1^{\text {st }}$ grade & 84 & 3.50 & .468 & & & & \\
grade & $2^{\text {nd }}$ grade & 58 & 3.20 & .432 & 3 & 16.119 & $0.001^{*}$ & Yes \\
& $3^{\text {rd }}$ grade & 104 & 3.44 & .480 & & & & $1-2$ \\
& $4^{\text {th }}$ grade & 63 & 3.37 & .430 & & & & \\
Academic & & & & & & & & \\
department & Teaching & 103 & 3.34 & .469 & & & & \\
& Training & 33 & 3.16 & .302 & 3 & 16.662 & $.003^{*}$ & Yes \\
& Management & 79 & 3.45 & .460 & & & & Management - Training \\
& Recreation & 94 & 3.49 & .489 & & & & Recreation - Training \\
\hline
\end{tabular}

In Table 3, average scores of SPES students' Emotional Intelligence Scale were compared in terms of some variables and results were presented. Students' emotional intelligence levels did not differ significantly in terms of age ( $p>0.05)$ whereas their emotional intelligence levels differed considerably in terms of academic grades and academic departments $(p<0.05)$. It was found that 1st grade students' emotional intelligence levels were partly higher than 2nd grade students' emotional intelligence levels. Besides, emotional intelligence levels of the students who studied at departments of Sports Management and Recreation were slightly higher than those students who attended department of Training. 
Table 4. Comparison of SPES students' emotional intelligence levels in terms of sex, sportive branches and type of high school variables

\begin{tabular}{llllllll}
\hline & & $\mathrm{n}$ & $\overline{\mathrm{X}}$ & $\mathrm{SD}$ & $\mathrm{U}$ & $\mathrm{p}$ & Difference \\
\hline Sex & Male & 155 & 3.34 & .455 & 10168.500 & $.024^{*}$ & Yes \\
& Female & 154 & 3.46 & .474 & & & \\
Sportive branch & & & & & & \\
& Team sports & 182 & 3.41 & .454 & 10832.000 & .348 & No \\
& Individual sports & 127 & 3.38 & .488 & & & \\
Type of high school & General high school & 205 & 3.41 & .475 & 10454.000 & .781 & No \\
& Vocational high school & 104 & 3.38 & .455 & & & \\
\hline
\end{tabular}

In Table 4, average scores of SPES students' Emotional Intelligence Scale were compared in terms of some variables and results were presented. Students' emotional intelligence levels did not differ significantly in terms of sportive branches and types of high schools where they graduated ( $>0.05)$; their emotional intelligence levels differed considerably in terms of sex variable $(p<0.05)$. It was identified that Female students' emotional intelligence levels were partly higher than male students.

Table 5. Average scores of SPES students from total time management inventory and its subdimensions

\begin{tabular}{llll}
\hline Time Management Inventory & $\mathrm{n}$ & $\overline{\mathrm{X}}$ & $\mathrm{Sd}$ \\
\hline Long-range planning & 309 & 3.24 & .692 \\
Time attitudes & 309 & 3.22 & .491 \\
Short-range planning & 309 & 3.10 & .895 \\
General Average Scores & 309 & 3.22 & .467 \\
\hline
\end{tabular}

Table 5 demonstrated the participant SPES students' average scores obtained from total Time Management Inventory and its subdimensions. Accordingly; it was found that students' total average score from the Time Management Inventory was $\overline{\mathrm{X}}=3.22$. Besides, students' average score was $\overline{\mathrm{X}}=3.24$ from Long-range planning subdimension, $\bar{X}=3.22$ from Time attitudes subdimension and $\bar{X}=3.10$ from Short-range planning subdimension.

Table 6. Comparison of SPES students' time management skills in terms of age, academic grades and academic department variables

\begin{tabular}{|c|c|c|c|c|c|c|c|}
\hline & & $\mathrm{n}$ & $\overline{\mathrm{X}}$ & $\mathrm{Sd}$ & $\mathrm{F}$ & $\mathrm{p}$ & Difference \\
\hline \multirow{3}{*}{ Age } & $18-20$ & 122 & 3.19 & .454 & & & \\
\hline & $21-23$ & 148 & 3.23 & .445 & .392 & .676 & No \\
\hline & $24-26$ & 39 & 3.24 & .587 & & & \\
\hline \multirow{4}{*}{ Academic grade } & $1^{\text {st }}$ grade & 84 & 3.21 & .443 & & & \\
\hline & $2^{\text {nd }}$ grade & 58 & 3.22 & .453 & .176 & .913 & No \\
\hline & $3^{\text {rd }}$ grade & 104 & 3.20 & .506 & & & \\
\hline & $4^{\text {th }}$ grade & 63 & 3.25 & .455 & & & \\
\hline \multirow{4}{*}{ Academic department } & Teaching & 103 & 3.19 & .472 & & & \\
\hline & Training & 33 & 3.18 & .445 & & & \\
\hline & Management & 79 & 3.25 & .480 & .388 & .762 & No \\
\hline & Recreation & 94 & 3.23 & .464 & & & \\
\hline
\end{tabular}

In Table 6, average scores of SPES students' Time Management Inventory were compared in terms of some variables and results were presented. Students' time management skills did not change significantly in terms of age, academic grades and academic departments $(\mathrm{p}<0.05)$. 
Table 7. Comparison of SPES students' time management skills in terms of sex, sportive branches and type of high school variables

\begin{tabular}{llllllll}
\hline & & $\mathrm{n}$ & $\overline{\mathrm{X}}$ & $\mathrm{SD}$ & $\mathrm{t}$ & $\mathrm{p}$ & Difference \\
\hline Sex & Male & 155 & 3.19 & .459 & -.985 & .326 & No \\
& Female & 154 & 3.24 & .476 & & & \\
& & & & & & \\
Sportive branch & Team sports & 182 & 3.20 & .458 & -.491 & .624 & No \\
& Individual sports & 127 & 3.23 & .482 & & & \\
& & & & & & & \\
\multirow{2}{*}{ Type of high school } & General high school & 205 & 3.22 & .480 & .157 & .876 & No \\
& Vocational high school & 104 & 3.21 & .443 & & & \\
\hline
\end{tabular}

In Table 3, average scores of SPES students' Time Management Inventory were compared in terms of some variables and results were presented. Students' time management skills did not differ significantly in terms of sex, sportive branches and type of high schools where they graduated $(\mathrm{p}<0.05)$.

Table 8. Correlation between SPES students' emotional intelligence levels and time management skills

\begin{tabular}{llll}
\hline & & Emotional intelligence & Time management \\
\hline Emotional intelligence & Pearson correlation & 1 & $.120^{*}$ \\
& Sig. (2-tailed) & & .034 \\
Time & $\mathrm{N}$ & 309 & 309 \\
management & Pearson correlation & $.120^{*}$ & 1 \\
& Sig. (2-tailed) & .034 & \\
& $\mathrm{n}$ & 309 & 309 \\
\hline
\end{tabular}

In Table 8, the correlation between SPES students' emotional intelligence levels and time management skills was presented. As a result of the analysis, it was found that the correlation between students' emotional intelligence levels and time management skills was positive and significant at $\mathrm{p}<0.05(\mathrm{r}=.120)$.

\section{Discussion and Conclusion}

In this study; emotional intelligence levels and time management skills of students of school of physical education and sports were explored and investigated in terms of some variables. As far as study results were concerned; emotional intelligence levels of SPES students were found to be at "moderate level". Students' emotional intelligence levels were also at "moderate level" in subdimensions of Optimism, Awareness-of-Emotions and Use-of-Emotions. Moreover; students' emotional intelligence levels differed considerably in terms of sex, academic grades and academic department variables while their emotional intelligence levels did not change considerably in terms of age, sportive branch and type of high school from which they graduated. On the other hand; according to study results time management skill levels of SPES students were found to be at "moderate level". Besides, time management skill levels were also at "moderate level" in subdimensions of Long-range planning, Time attitudes and Short-range planning. There were no any statistically significant differences in students' time management skills in terms of sex, academic grades, age, sportive branches, type of high school and academic department variables.

According to results of the studies done by Tok (2008), Karademir et al. (2010), Adiloğulları (2013); participants' emotional intelligence levels were found to be higher. Study results of the current study did not concur with the results of those studies above mentioned. On the other hand, the study of Tingaz (2013) found participants' emotional intelligence levels as moderate. Results of the current study were in line with the study of Tingaz (2013). In the study undertaken by Karademir et al. (2010), participants' emotional intelligence differed significantly in terms of age variable. Study results of the current study did not concur with the results of this study. According to the studied done by Adiloğulları (2013) and Özdinç \& Bilir (2016); participants' emotional intelligence did not change considerably in terms of age variable. Study results of the current study were in line with the results of these studies. On the other hand; the studies done by Taşkın (2008), Tok (2008), Yaşar (2010) reported no statistically significant difference in participants' emotional intelligence in terms of sex variable. Study results of the current study concurred with the results of this study. In the study of Taşkın (2008), participants' emotional intelligence levels did not change in terms of sportive branches and study results of the current study were in agreement with the results of these studies. In the study conducted by Yaşar (2010); there 
were significant differences in participants' emotional intelligence in terms of sportive branches; which contradicted study results of the current study.

As far as study results of the studies done by Dinçay (2010), Sugötüren (2011) and Caz \& Tunçkol (2015) were concerned; participants' time management skills were found to be at "moderate level" and thus study results of the current study were in agreement with the results of these studies. According to results of the studies conducted by Türkmen (2005), Caz \& Tunçkol (2015) and Dinçay (2010); participants' time management skills were significantly different in terms of sex and these studies contradicted study results of the current study in this sense. The study of Caz \& Tunçkol (2015) suggested that participants' time management skills differed in terms of academic grades and results of the current study did not concur with the study of Caz \& Tunçkol (2015). According to study of Gökçek (2013), participants' time management skills did not change considerably in terms of age and thus study results of the current study were in agreement with the results of this study.

That individuals possess high level of emotional intelligence and time management skills may generate positive outcomes in every aspect and therefore conferences-seminars can be held for students to enhance their emotional intelligence levels and time management skills. Different training programs may be organized and thus students are made more aware of emotional intelligence and time management skills. Besides, it can be investigated why emotional intelligence and time management skills of students who studied at school of physical education and sports are at moderate level.

\section{References}

Adiloğulları, G. E. (2013). Beden eğitimi öğretmenlerinin duygusal zeka ile mesleki tükenmişlik düzeyleri arasındaki ilişkinin incelenmesi. Yüksek Lisans Tezi, Kahramanmaraş Üniversitesi, Sağlık Bilimleri Enstitüsü, Kahramanmaraş.

Alay, S. (2000). Seçilmiş Üniversite Öğrencilerinin Zaman Yönetimi Ve Akademik Başarıları Arasındaki İlişki. Yüksek Lisans Tezi, Orta Doğu Teknik Üniversitesi Sosyal Bilimler Enstitüsü.

Alay, S., \& Kocak, S. (2002). Validity and Reliability of Time Management Questionnaire. Hacettepe Üniversitesi Eğitim Fakültesi Dergisi, 22(22).

Britton, B. K., \& Tesser, A. (1991). Effects of Time Management Practices on College Grades. Journal of Educational Psychology, 83(3), 405-410. https://doi.org/10.1037/0022-0663.83.3.405

Çağdaş, C. A. Z., \& Tunçkol, H. M. (2015). Beden Eğitimi Öğretmenlerinin Zaman Yönetimi Becerilerinin İncelenmesi. Spor Ve Performans Araştırmaları Dergisi, 6(2), 91-100.

Dinçay, H. (2010). Seçilmiş Üniversite Öğrencilerinin Zaman Yönetimi Becerileri ve Fiziksel Aktivite Düzeyleri Arasındaki İlişki. Yüksek Lisans Tezi. Orta Doğu Teknik Üniversitesi, Sosyal Bilimler Enstitüsü, Beden Eğitimi ve Spor Bölümü, Beden Eğitimi ve Spor Anabilim Dalı,

Dökmen, Ü. (2004). Varolmak, Gelişmek, Uzlaşmak. İstanbul: Sistem Yayınc1lık.

Epstein, R. (1999). The Key to Our Emotions. Psychology Today, 32(4).

Erdoğdu, M. Y. (2008). Duygusal Zeka’nın Bazı Değişkenler Açısından İncelenmesi. Elektronik Sosyal Bilimler Dergisi, 23(23).

Gökçek, A. (2013). Profesyonel Futbol Takımlarında Görev Yapan Yöneticilerin Zaman Yönetimi Ankara İli Örneği. Yüksek Lisans Tezi. Gazi Üniversitesi, Eğitim Bilimleri Enstitüsü, Beden Eğitimi ve Spor Öğretmenliği Anabilim Dalı.

Güçlü, N. (2001). Zaman Yönetimi. Kuram Ve Uygulamada Eğitim Yönetimi, 7(1), 87-100.

Gün, N. (2006). Zaman Yönetimi (1440 Dakika). İstanbul: Kuraldışı Yayıncılık.

Haynes, M. E. (1999). Kişisel Zaman Yönetimi. (Y. Bülbül, Çev.). İstanbul: Alfa Basım Yayım Dağıtım Ttd. Şti.

James, J. (1997). Gelecek Zamanda Düşünmek (Çev.: Zülfü Dicleli). İstanbul: Boyner

Karademir, T., Döşyılmaz, E., Çoban, B., \& Kafkas, M. E. (2010). Beden eğitimi ve spor bölümü özel yetenek sınavına katılan öğrencilerde benlik saygısı ve duygusal zeka. Kastamonu Eğitim Dergisi, 18(2), 653-674.

Karaköse, T. (2009). Okul Müdürlerinin Bireysel Zaman Yönetimi Becerileri. Akademik Araştırmalar Dergisi, $11(42), 149-160$.

Karaoğlan, A. D. (2006). Üst Düzey Yöneticilerin Zaman Yönetimi. Yüksek Lisans Tezi, Balıkesir Üniversitesi Fen Bilimleri Enstitüsü. 
Keenan, K. (1996). Yöneticinin Kılavuzu Zamanı Doğru Kullanma. Çev.:E. Koparan, Remzi Kitabevi, İstanbul, $64 \mathrm{~s}$.

Konrad, S., \& Ve Hendl, C. (2003). Duygularla Güçlenmek, İstanbul: Hayat Yayınları.

Mayer, J. D., \& Salovey, P. (1997). What Is Emotional Intelligence. In P. Salovey \& D. Sluyter (Eds.), Emotional Development and Emotional Intelligence: Educational Implications (pp. 3-34). New York: Basicbooks, Inc.

Özdinç, Ö., \& Bilir, F. (2016). Üst Düzey Spor Örgüt Yöneticilerinin Duygusal Zeka Özelliklerini Belirlemeye Yönelik Bir Çalışma. Spor Bilimleri Dergisi, 27(1), 27-39. Retrieved From Http://Dergipark.Gov.Tr/Sbd/İssue/22939/251311

Salovey, P., \& Mayer, J. D. (1990). Emotional Intelligence. Imagination, Cognition and Personality, 9, 185-211. https://doi.org/10.2190/DUGG-P24E-52WK-6CDG

Schutte, N. S., Malouff, J. M., Hall, L. E., Haggerty, D. J., Cooper, J. T., Golden, C. J., \& Dornheim, L. (1998). Development and validation of a measure of emotional intelligence. Personality and Individual Differences, 25(2), 167-177. https://doi.org/10.1016/S0191-8869(98)00001-4

Sugötüren, M., Mülazımoğlu Ballı, Ö., \& Gökçe, H. (2011). Spor Bilimleri Ve Teknolojisi Yüksekokulunda Öğrenim Gören Öğrencilerin Zaman Yönetimi Davranışları. Spormetre Beden Eğitimi Ve Spor Bilimleri Dergisi, 9(3), 91-96. https://doi.org/10.1501/Sporm_0000000204

Taşkın A. K. (2008). Beden Eğitimi Öğrencilerinde Duygusal Zeka Düzeylerinin Bazı Değişkenlere Göre İncelenmesi Selçuk Üniversitesi / Sağlık Bilimleri Enstitüsü / Beden Eğitimi Ve Spor Anabilim Dalı Yüksek Lisans Tezi

Tatar, A., Tok, S., \& Ve Saltukoğlu, G. (2011). Araştırmalar/Original Papers Gözden Geçirilmiş Schutte Duygusal Zekâ Ölçeğinin Türkçe'ye Uyarlanması ve Psikometrik Özelliklerinin İncelenmesi. Klinik Psikofarmakoloji Bülteni 2011, 21(4), 325-338. https://doi.org/10.5455/bcp.20110624015920

Tok, S. (2008). Performans Sporcusu Ve Spor Yapmayan Üniversite Öğrencilerinde Duygusal Zeka İle Kişilik Özelliklerinin Karşılaştırılması. Yayınlanmamış Doktora Tezi. Ege Üniversitesi Sağlık Bilimleri Enstitüsü.

Türkmen, M. (2015). Gençlik Ve Spor Genel Müdürlüğü Merkez Örgütünde Zaman Yönetimi, Yüksek Lisans Tezi, Sakarya Üniversitesi Sosyal Bilimler Enstitüsü).

Ural, A. (2001). Yöneticilerde Duygusal Zekânın Üç Boyutu. Dokuz Eylül Üniversitesi Sosyal Bilimler Enstitüsü Dergisi, 3(2), 209-219.

Ünlü, B., Çevik, E. E., \& Kurnaz, M. A. (2017). Okul Öncesi Öğretmen Adaylarının Duygusal Zekâlarının Çeşitli Değişkenler Açısından İncelenmesi. Kastamonu Eğitim Dergisi, 24(5), 2425.

Weisinger, H., (1998). İş yaşamında Duygusal Zeka. Çeviren: Nurettin Süleymangil. İstanbul: MNS Yayıncılık.

Yaşar, M. (2010). Duygusal Zeka Ve Sporcu Performansı İlişkisi: Kayseri’de Bir Araştırma. Yüksek Lisans Tezi. Erciyes Üniversitesi, Sosyal Bilimler Enstitüsü, Spor Yöneticiliği Anabilim Dalı.

\section{Copyrights}

Copyright for this article is retained by the author(s), with first publication rights granted to the journal.

This is an open-access article distributed under the terms and conditions of the Creative Commons Attribution license (http://creativecommons.org/licenses/by/4.0/). 